NAA-SR-4388

COPY

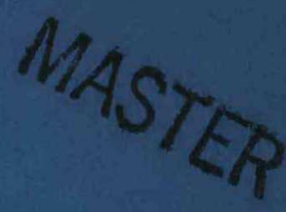

\title{
A LINEAR INDUCTION PUMP \\ FOR LIQUID METALS
}

AEC Research and Development Report

\section{ATOMICS INTERNATIONAL}

A DIVISION OF NORTH AMERICAN AVIATION, INC. 


\section{DISCLAIMER}

This report was prepared as an account of work sponsored by an agency of the United States Government. Neither the United States Government nor any agency Thereof, nor any of their employees, makes any warranty, express or implied, or assumes any legal liability or responsibility for the accuracy, completeness, or usefulness of any information, apparatus, product, or process disclosed, or represents that its use would not infringe privately owned rights. Reference herein to any specific commercial product, process, or service by trade name, trademark, manufacturer, or otherwise does not necessarily constitute or imply its endorsement, recommendation, or favoring by the United States Government or any agency thereof. The views and opinions of authors expressed herein do not necessarily state or reflect those of the United States Government or any agency thereof. 


\section{DISCLAIMER}

Portions of this document may be illegible in electronic image products. Images are produced from the best available original document. 


\section{LEGAL NOTICE}

This report was prepared as an account of Government sponsored work. Neither the United States, nor the Commission, nor any person acting on behalf of the Commission:

A. Makes any warranty or representation, express or implied, with respect to the occuracy, completeness, or usefulness of the information contained in this report, or that the use of any information, apparatus, method, or process disclased in this report may not infringe privately owned rights; or

B. Assumes any liabilities with respect to the use of, or for damages resulting from the use of information, apparatus, method, or process disclased in this roport.

As used in the above, "parson acting on behalf of the Commission" includes any am, playee or contractor of the Commission to the extent that such employea or contracter prepares, handles or distributes, or provides access to, any information pursuant to his employment or contract with the Commission.

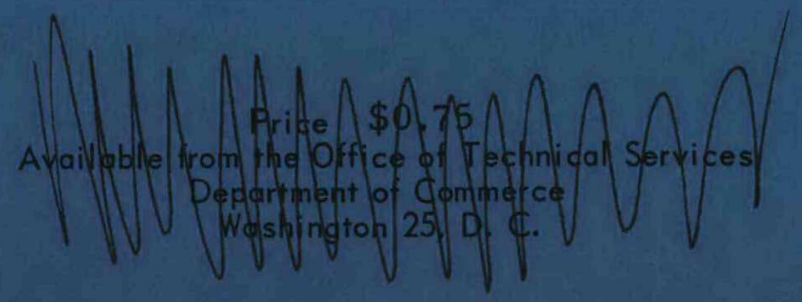




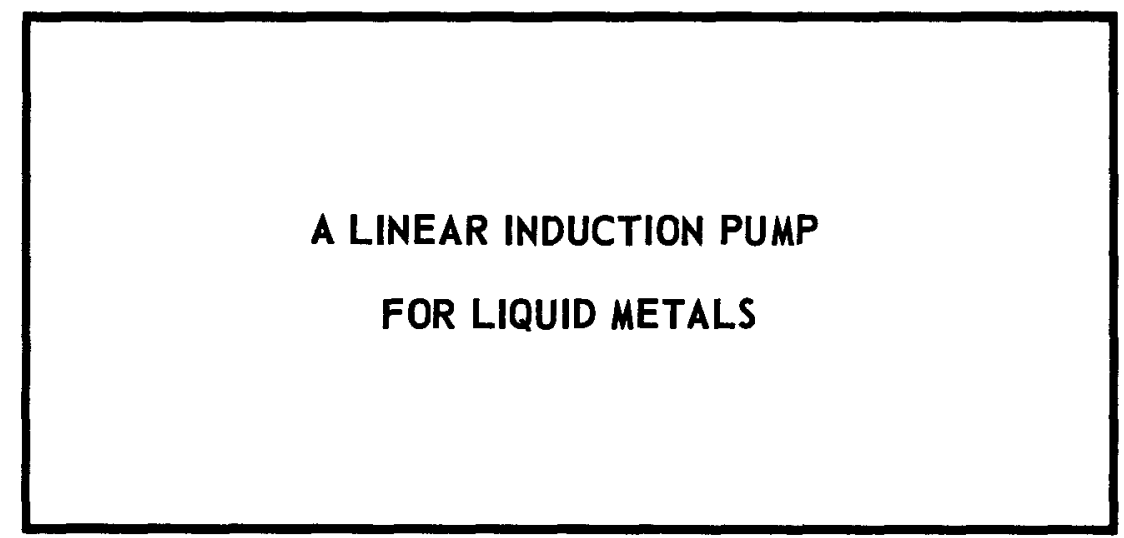

By

R. S. BAKER

\section{ATOMICS INTERNATIONAL}

A DIVISION OF NORTH AMERICAN AVIATION, INC.

P.O. BOX 309 CANOGA PARK, CALIFORNIA

CONTRACT: AT(11-1)-GEN-8

ISSUED: JAN 151960 


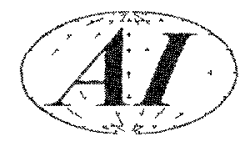

\section{DISTRIBUTION}

This report has been distributed according to the category "ReactorsGeneral" as given in "Standard Distribution Lists for Unclassified Scientific and Technical Reports" TID-4500 (15th Ed.), August 1, 1959. A total of 620 copies was printed. 


\section{CONTENTS}

Page

Abstract . . . . . . . . . . . . . . . . . . . . . $\quad$. v

I. Introduction

A. General

B. Pump Description

1. Pump Stator

2. Control of Flow Rate . . . . . . . . . . . . . . . 3

II. Description of the Apparatus Used in the Pump Test . . . . . . 4

A. Pump Details. . . . . . . . . . . . . . . . . . 4

1. Stator. . . . . . . . . . . . . . . . . . . 4

2. Flux Return Path . . . . . . . . . . . . . . . 4

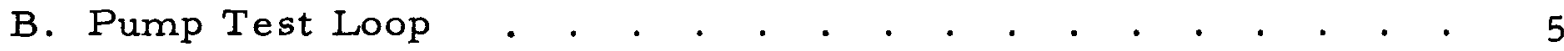

C. Flow Rate Control . . . . . . . . . . . . . . . . 5

D. Auxiliary Cooling Equipment . . . . . . . . . . . . . 6

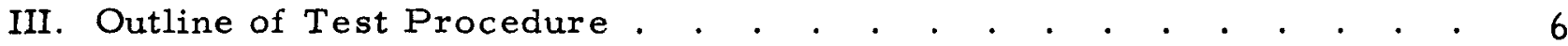

IV. Processing of Test Data. •

A. Calculation of Pressure Rise Across Pump . . . . . . . . $\quad 7$

B. Calculation of Pump Efficiency . . . . . . . . . . . . . . $\quad$. 7

V. Discussion of Curves Obtained from Pump Test. . . . . . . . $\quad$. 8

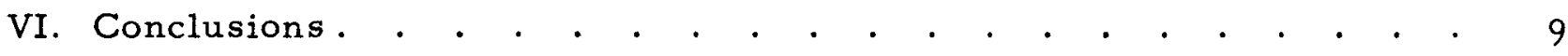

Appendix . . . . . . . . . . . . . . . . . . . .

A. Design Procedure . . . . . . . . . . . . . . . . . 10

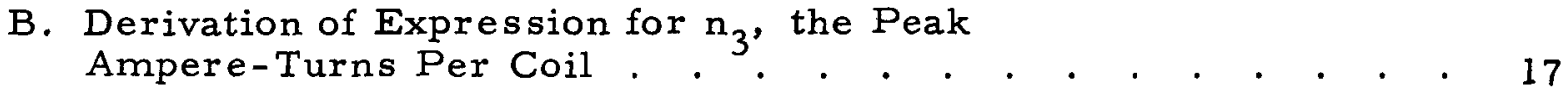

\begin{tabular}{l} 
C. Derivation of the Factor 0.435 in the Equation \\
for Efficiency (IV B)... \\
\hline
\end{tabular}

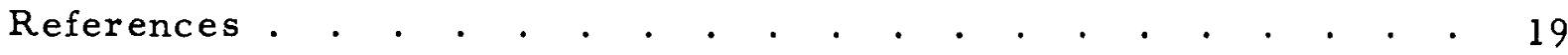




\section{FIGURES}

1. Schematic View of Overflow Reactor . . . . . . . . . . . vi

2. Top View of Reactor Showing Pumps . . . . . . . . . . . 2

3. Photograph of Pump on Test Loop . . . . . . . . . . . . . . 2

4. Elevation of Pump Test Loop. . . . . . . . . . . . . . . 4

5. Stator Lamination . . . . . . . . . . . . . . . . . 4

6. Stator Coil . . . . . . . . . . . . . . . . . . . . 5

7. Cutaway View of Tank and Pump . . . . . . . . . . . . 5

8. Top View of Test Loop Tank and Pump . . . . . . . . . . 6

9. Curve of Pressure vs Flow . . . . . . . . . . . . . . . .

10. Curve of Efficiency vs Flow . . . . . . . . . . . . . . . $\quad 8$ 


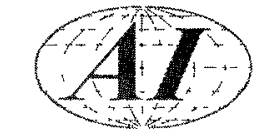

\begin{abstract}
A linear induction pump of a special design was used to circulate molten sodium through a mockup of an experimental "overflow" type of sodium-cooled reactor.

The distinctive features of this pump are that no seals or moving parts are required; no piping is required to carry sodium to the pump or away from it because the pump is mounted directly on the reactor vessel, with the windings outside of the vessel and the magnetic flux return path inside the vessel.

The pump develops 342 gpm at 6.2 psi when pumping sodium having a temperature of $600^{\circ} \mathrm{F}$ with an efficiency of $4.7 \%$.
\end{abstract}



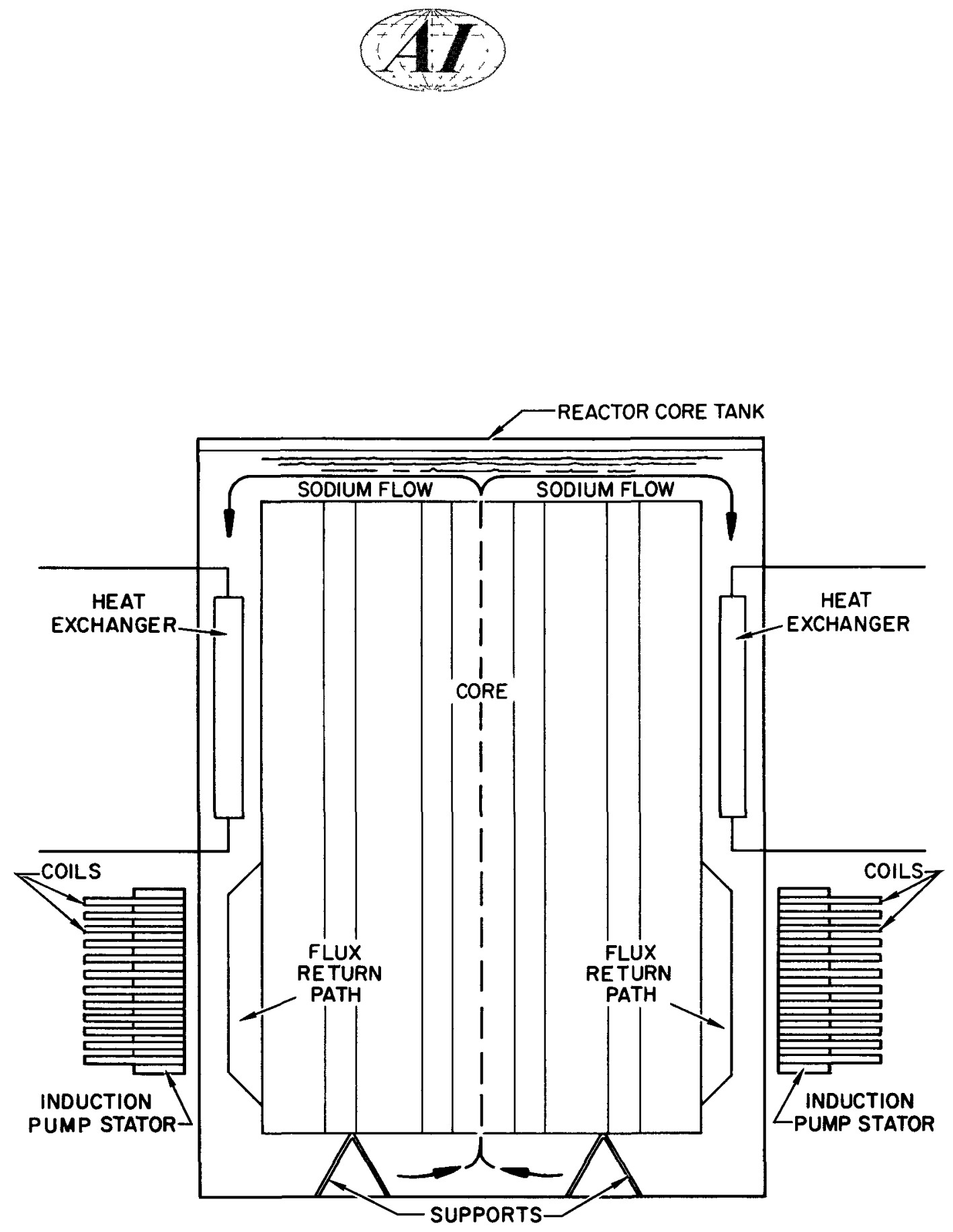

Figure 1. Schematic View of Overflow Reactor 


\section{(AI)}

\section{INTRODUCTION}

\section{A. GENERAL}

Liquid metal-cooled reactors can be operated quite satisfactorily with electromagnetic pumps. Commercial "in-line" pumps are available, and theory of their operation is well known. In order to perform service on these pumps, they must generally be removed from the piping system in which they are installed, and at the very least, the compartment in which they are located must be entered. Because of the induced radioactivity in the primary circuits of sodium cooled reactors, this often results in a delay while $\mathrm{Na}-24$ activity is decaying.

In an attempt to minimize down-time necessitated by sodium decay, a primary circuit completely enclosed in a single tank has been proposed. In order to circulate sodium past the various heat transfer components installed in this tank, an electromagnetic pump, in which removable windings are outside the primary tank, was designed. These windings, which are the most likely parts of the pump to require maintenance, are not in contact with liquid metal and are not significantly activated by neutron bombardment because of neutron shields placed within the reactor tank. Only magnetic flux return paths of silicon steel, jacketed with stainless steel, are actually placed in the sodium; no maintenance problems are expected from these flux return paths. Therefore, maintenance or replacement of vital parts of these pumps could be expected not to create long delays when the system is shut down for maintenance.

In order to demonstrate the feasibility of this concept, and to check theoretical performance predictions, a mockup of this pump was made and tested. All components then were sized to fit a proposed experimental reactor; performance exceeded predicted values of flow, pressure rise, and efficiency.

\section{B. PUMP DESCRIPTION}

Each pump consists of two major parts: these are the stator and the flux return path. The stator is outside the annulus; the flux return path is inside the annulus (Figures 1 and 2).

\section{Pump Stator}

The stator has a distributed winding similar to that of an ordinary 3-phase motor; when the windings are connected to a 3-phase source of power, current 


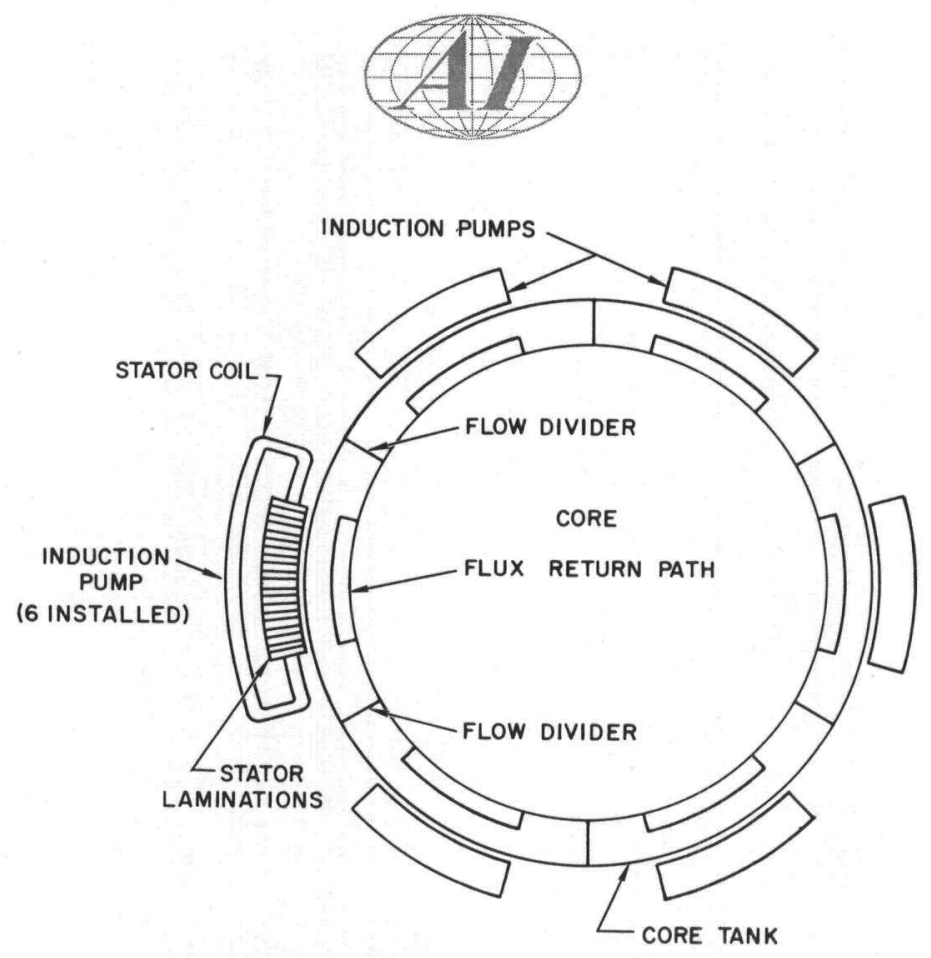

Figure 2. Top View of Reactor Showing Pumps

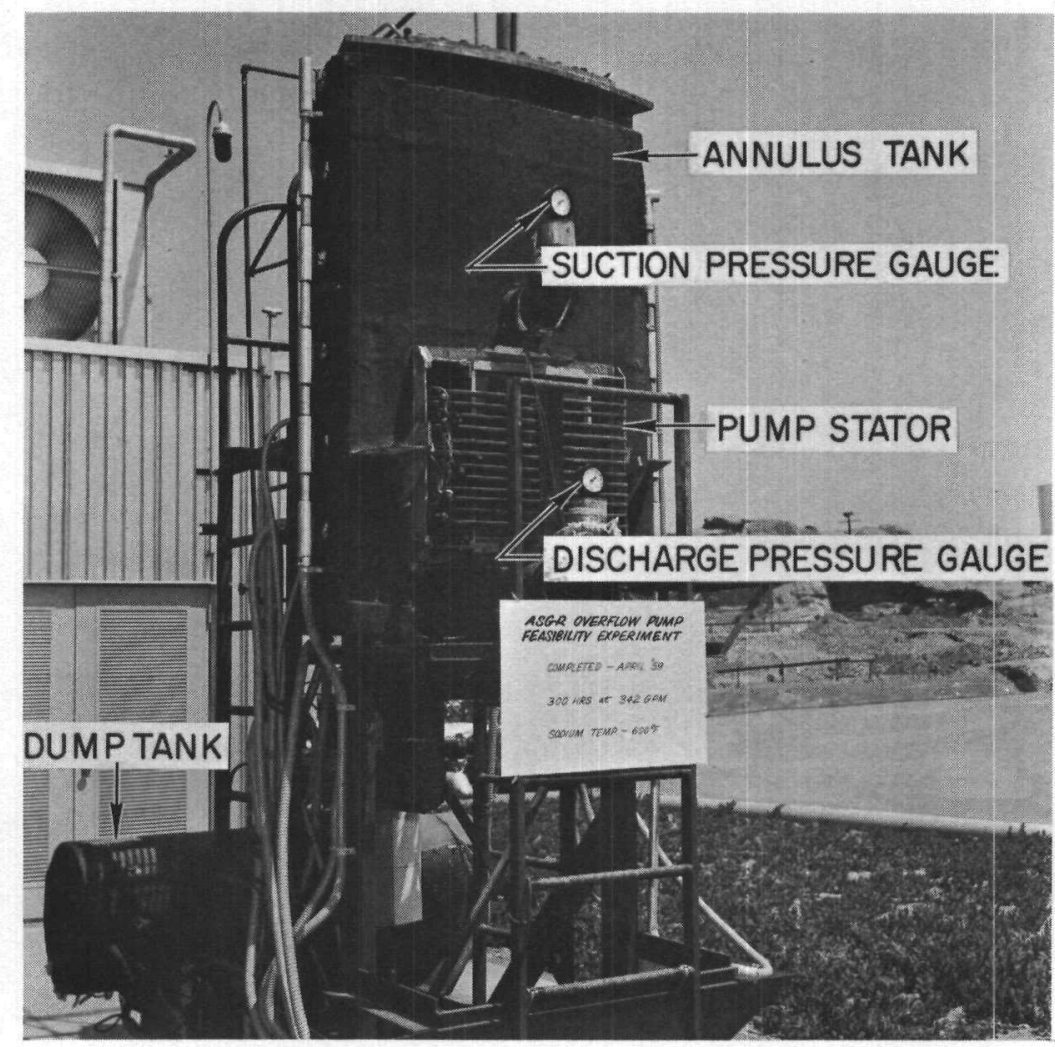

Figure 3. Photograph of Pump on Test Loop 


\section{(1)}

flowing in the stator windings sets up magnetic flux which passes through the outer wall of the annulus, through the sodium, into the flux return path, within the flux return path in a vertical direction, then back out through the sodium and annulus wall to the stator.

As the currents in successive portions or "pole-phase-groups" of the vertically distributed stator winding come to maximum values, the magnetic flux in the sodium moves downward inducing eddy-currents in the sodium. Reaction between the magnetic fields of eddy-currents and stator currents causes pumping action to take place.

A distinctive feature of this pump is its division into an active magnetic surface (the stator) and a passive magnetic surface (the flux return path). A linear induction pump, as ordinarily constructed, has the stator in two parts, one on each side of the sodium passage. $2,3,4$

Another distinctive feature of this pump is its coil construction. The coil is flat, which makes it easy to wind. The coil arrangement permits circulation of cooling air to three-fourths of the coil surface. (See Figures 3, 6, and 8.)

Another advantage of the coil construction is that each coil (or pair of adjacent coils) is required to satisfy the magnetic field conditions at only one location. In ordinary linear induction pump construction, each coil is shaped so that both sides are in slots which are spaced nearly one pole pitch apart. The discontinuous or open-ended magnetic circuit, in a linear induction pump, causes the character of the magnetic field to be different in the mid-portion of the pump as compared to its character at the ends. This means that the magnetizing current in each coil of an ordinary linear induction pump cannot satisfy the air-gap magnetic field conditions at the coil side locations.

\section{Control of Flow Rate}

Flow rate control is achieved by adjustment of the a-c voltage supplied to the pump terminals. This requires the use of a device such as a variable-voltage autotransformer, or an induction voltage regulator. Saturable-core reactors may be used in place of the autotransformer or the regulator. 


\section{DESCRIPTION OF THE APPARATUS USED IN THE PUMP TEST}

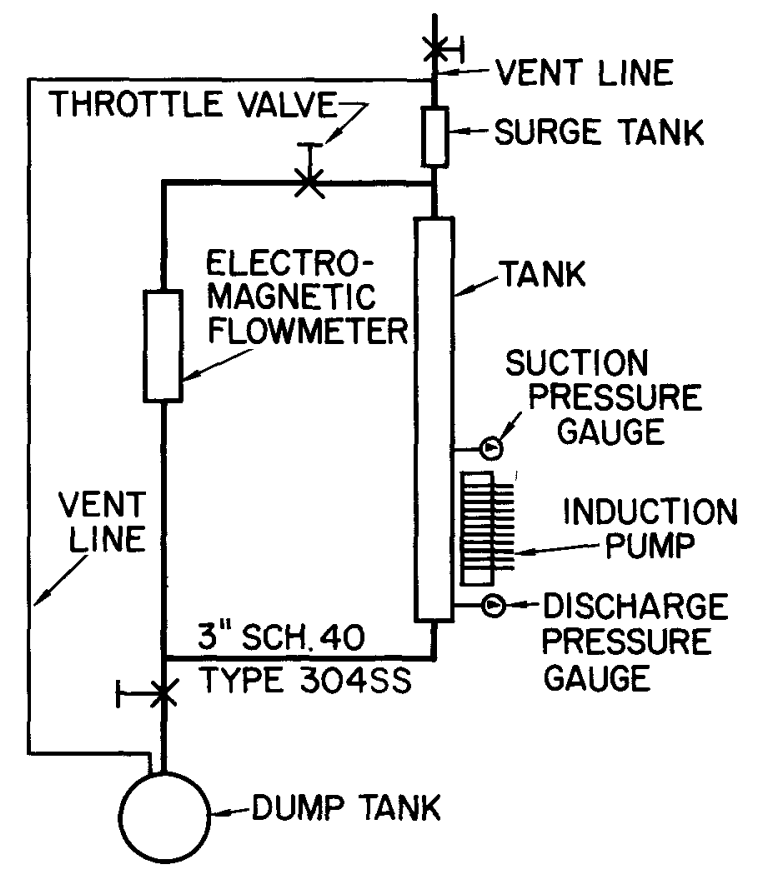

Figure 4. Elevation of Pump Test Loop

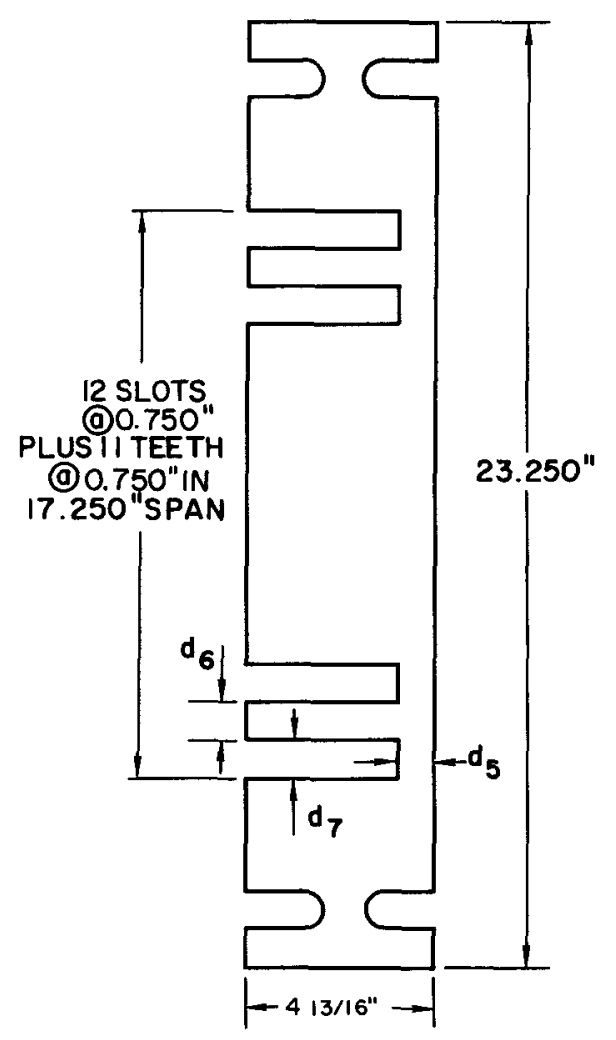

Figure 5. Stator Lamination
Refer to Figure 3, which shows the pump mounted on the test loop and to Figure 4, which is a schematic elevation of the test loop. It must be kept in mind that the only purpose of the pipe circuit was to provide a loop for circulation of sodium to obtain test data. In an actual installation of the pump on a reactor, the pump "loop" would consist of the annulus and core passages.

\section{A. PUMP DETAILS}

\section{Stator}

The pump stator consists of a 17.5 in. wide stack of steel laminations each 0.014 in. thick, with slots as shown in Figure 5. The stator winding consists of 12 coils; a typical coil is detailed in Figure 6.

\section{Flux Return Path}

The flux return path consists of silicon steel laminations having the same thickness and width as the stator, but without slots. The flux return path is sealed in a jacket of stainless steel 1/16-in. thick to prevent sodium from coming in contact with the silicon steel.

The stator and flux return path are mounted opposite each other with the stator on the outside and the flux return path on the inside of a tank which is part of the test loop. 


\section{(AI)}

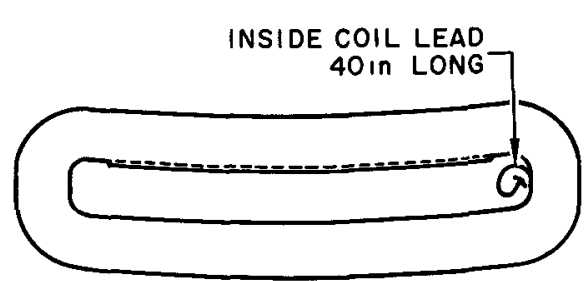

Figure 6. Stator Coil

\section{B. PUMP TEST LOOP}

The pump test loop is fabricated from Type 304 stainless steel; all piping in contact with sodium is 3 -in. schedule 40 . The vent lines are 1 -in. mild steel pipe. The outer and inner annulus walls are 1/4-in.

thick. Figure 7 is a cutaway view of the tank showing relative positions of stator and flux return path in addition to some of the tank dimensions. Figure 8 is a top view showing width of stator and flux return path. Suction and discharge pressure gauges and an electromagnetic flowmeter are used to obtain pressure rise and flow rate developed by the pump. The throttling valve is used to simulate a variable hydraulic load.

\section{FLOW RATE CONTROL}

Control of pump current is obtained through the use of a variable auto-transformer having an output rating of $90 \mathrm{amp}$ at $540 \mathrm{v}, 3$-phase, 60-cycle.

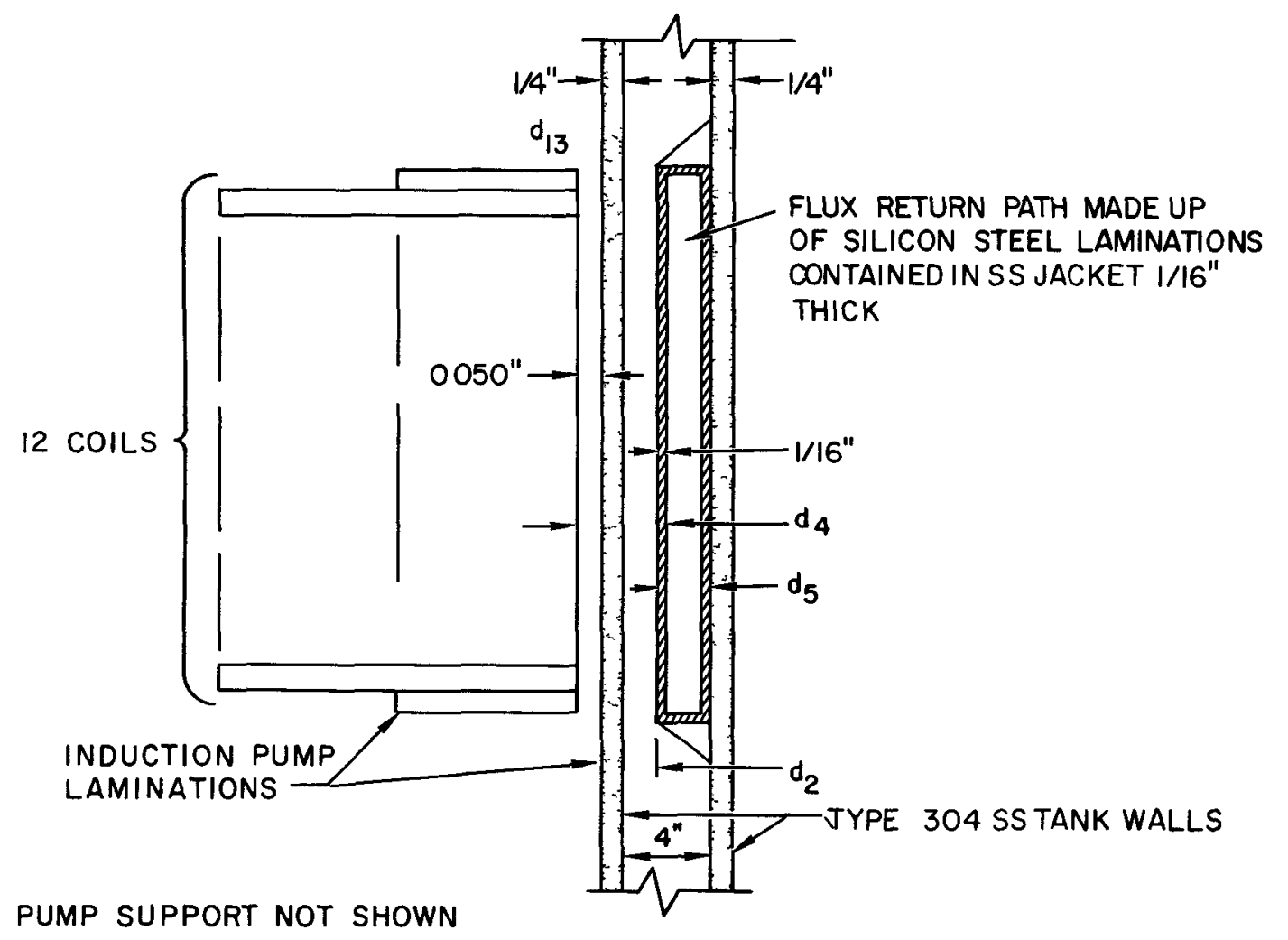

Figure 7. Cutaway View of Tank and Pump 


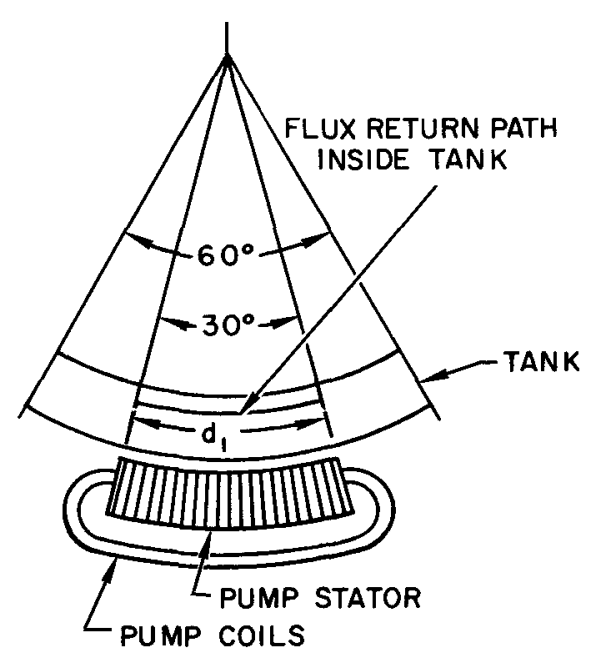

Figure 8. Top View of Test

Loop Tank and Pump

\section{AUXILIARY COOLING EQUIPMENT}

A blower of $900 \mathrm{ft}^{3} /$ min capacity fur nishes cooling air to the stator coils. The blower keeps the outside coil surface temperature from exceeding $300^{\circ} \mathrm{F}$ after 8 hours of steady-state operation when pumping sodium at $600^{\circ} \mathrm{F}$. The coil temperature is measured by a surface thermocoupletype pyrometer held against the surface of a coil where the coil emerges from the stator slot.

\section{OUTLINE OF TEST PROCEDURE}

After first drying the loop and purging with inert gas, all parts to be in contact with sodium were preheated to $350^{\circ} \mathrm{F}$ with rod heaters. When the loop was filled with sodium, with the throttle valve wide open, the pump was energized from a 3-phase source at $400 \mathrm{v}$ obtained by means of a variable autotransformer. Readings were taken of suction and discharge pressures, flow rate, and power input to the pump.

The flow was reduced $10 \%$ by the throttling valve, and readings were taken again. This procedure was followed until shutoff valve position was reached. At each step, the flow was reduced by $10 \%$ of that obtained when the valve was wide open.

Sodium temperature was maintained at an average value of $600^{\circ} \mathrm{F}$, with swings of $\pm 75^{\circ} \mathrm{F}$. 


\section{(A1)}

\section{PROCESSING OF TEST DATA}

A. CALCULATION OF PRESSURE RISE ACROSS PUMP

The net pressure rise across the pump is the difference between discharge and suction pressures, corrected for the difference in initial readings of the discharge and suction pressure gauges (Figures 3 and 4).

To illustrate the procedure for calculating net pressure rise, assume that with the pump ready for a test run, the readings on the gauges before turning on the power are $P_{1}$ psi on the discharge gauge and $P_{2}$ psi on the suction gauge. Assume that after turning on the power, the discharge gauge reads $P_{D}$ psi and the suction gauge reads $P_{S} p s i$, and that the flow of sodium is $Q$ gallons per minute. The net pressure rise $P$ due to pump action is

$$
P=\left(P_{D}-P_{1}\right)-\left(P_{S}-P_{2}\right)=P_{D}-P_{1}+P_{2}-P_{S}
$$

B. CALCULATION OF PUMP EFFICIENCY

The efficiency $\underline{e}$ is calculated from the equation

$$
\underline{\mathrm{e}}=\frac{0.435 \mathrm{PQ}}{\text { Power input to pump }} \text {. }
$$

See Appendix $C$ for derivation of the factor 0.435 . 


\section{DISCUSSION OF CURVES OBTAINED FROM PUMP TEST}

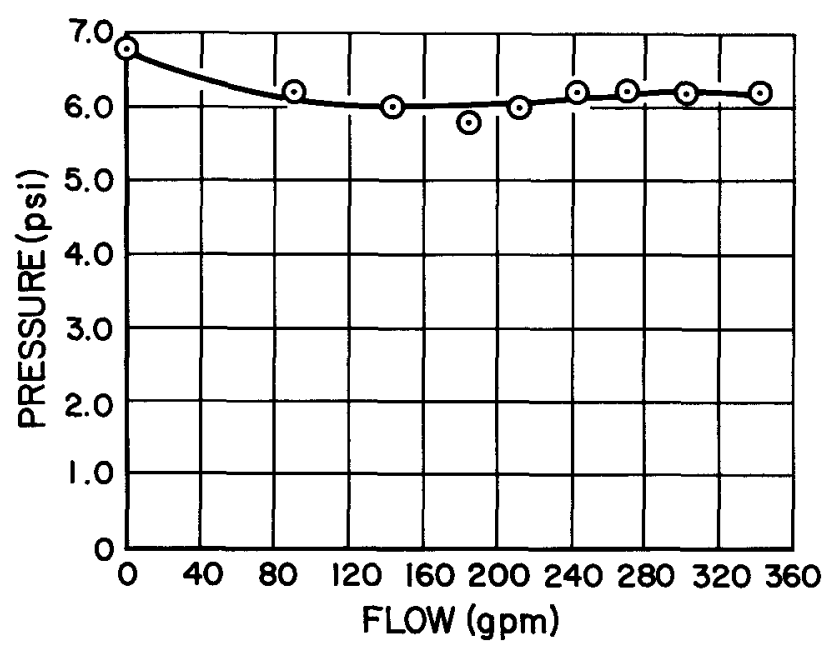

Figure 9. Curve of Pressure vs Flow

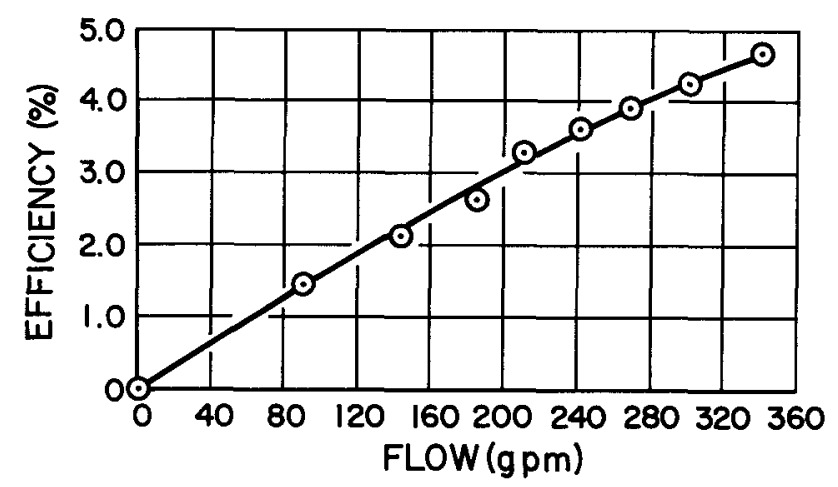

Figure 10. Curve of Efficiency vs Flow
The curve for pressure vs flow of this pump (Figure 9) shows a relationship which is typical for an induction pump. It is possible to design an induction pump that will develop its maximum pressure at any flow from shutoff to a flow which will be within $10 \%$ of synchronous flow. Synchronous flow is the flow rate that would be obtained if the sodium traveled through the pump at the velocity of the traveling field. In this respect, induction pump design follows the same pattern as induction motor design, in that an induction motor can be designed for maximum torque at speeds from standstill up to about $5 \%$ of synchronous speed.

The curve of efficiency vs flow of this pump (Figure 10) shows that the maximum efficiency occurs at some flow rate above the highest flow rate obtained (342 gpm). This is a typical relationship for an induction pump. 


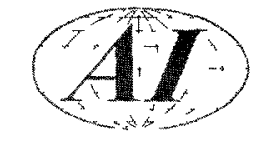

\section{CONCLUSIONS}

The pump met the flow rate requirement of $240 \mathrm{gpm}$; the pressure rise across the pump at this flow rate was 6.1 psi. The specified requirement of 10 psi could not be met due to the limit imposed by the rating of the variable autotransformer which supplied the pump.

The results obtained in the pump tests verify the application of Rudenberg's equation ${ }^{4}$ to the design of this type of electromagnetic pump. The procedure that is given in this report can be used to design similar larger induction pumps for reactors whose outputs may run to hundreds of megawatts. 


\section{(11)}

\section{APPENDIX}

\section{A. DESIGN PROCEDURE}

This is the procedure that was followed in designing the linear induction pump for the mockup test of the overflow type reactor.

\begin{tabular}{|c|c|c|}
\hline Symbol & Meaning & Magnitude \\
\hline $\mathbf{Q}$ & Volumetric flow rate of liquid metal through pump. & $240 \mathrm{gpm}$ \\
\hline $\mathrm{V}_{1}$ & $\begin{array}{l}\text { Velocity of liquid metal through pump. The magnitude } \\
\text { of } V_{1} \text { was set at } 156 \mathrm{in.} / \mathrm{sec} \text { from hydraulic considera- } \\
\text { tions. }\end{array}$ & 156 in. / sec \\
\hline$P$ & $\begin{array}{l}\text { Pressure to be developed by the pump, measured across } \\
\text { the pump at points of connection to the pipe system. }\end{array}$ & $10 \mathrm{psi}$ \\
\hline $\mathrm{d}_{1}$ & $\begin{array}{l}\text { Width of liquid metal path. See Figure } 8 \text {. This quan- } \\
\text { tity is fixed by the reactor design. }\end{array}$ & $17.5 \mathrm{in.}$ \\
\hline $\mathrm{d}_{2}$ & $\begin{array}{l}\text { Thickness of liquid metal path (Figure 7) } \\
\qquad \mathrm{d}_{2}=\frac{3.85 \mathrm{Q}}{\mathrm{v}_{1} \mathrm{~d}_{1}} .\end{array}$ & $0.400 \mathrm{in}$. \\
\hline$f$ & Frequency of power source. & $60 \mathrm{cps}$ \\
\hline $\mathrm{d}_{3}$ & $\begin{array}{l}\text { Pole pitch. The procedure is to as sume an initial } \\
\text { value for } d_{3} \text {, then work out the coil current } I_{3} \text {, and } \\
\text { recheck } d_{3} \text { to make certain that the pump will fit into } \\
\text { the available space. The value given here is the final } \\
\text { value after two trials. }\end{array}$ & 9 in. \\
\hline$r_{1}$ & $\begin{array}{l}\text { Electrical resistivity of liquid metal. For sodium, } \\
\text { the value of } r_{1} \text { at the desired operating temperature } \\
\text { of } 600^{\circ} \mathrm{F} \text { is } 7.1 \times 10^{-6} \mathrm{ohm}-\mathrm{in} .^{5}\end{array}$ & $\begin{array}{l}7.1 \times 10^{-6} \\
\text { ohm-in. }\end{array}$ \\
\hline$r_{2}$ & $\begin{array}{l}\text { Electrical resistivity of Type } 304 \text { stainless steel. The } \\
\text { value of } \mathrm{r}_{2} \text { at } 600^{\circ} \mathrm{F} \text { is } 36.8 \times 10^{-6} \mathrm{ohm-in.}\end{array}$ & $\begin{array}{l}36.8 \times 10^{-6} \\
\text { ohm-in. }\end{array}$ \\
\hline
\end{tabular}




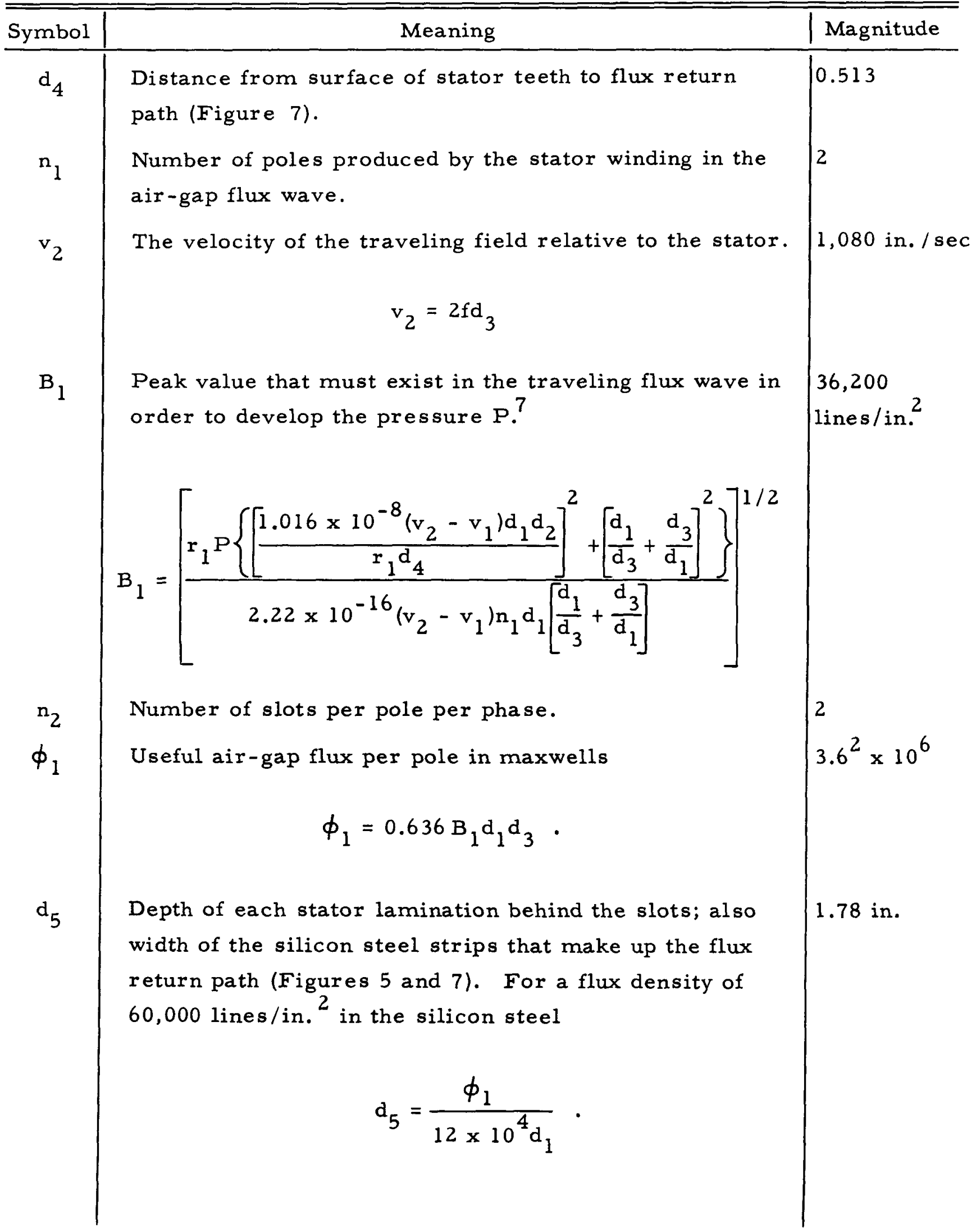




\section{AI}

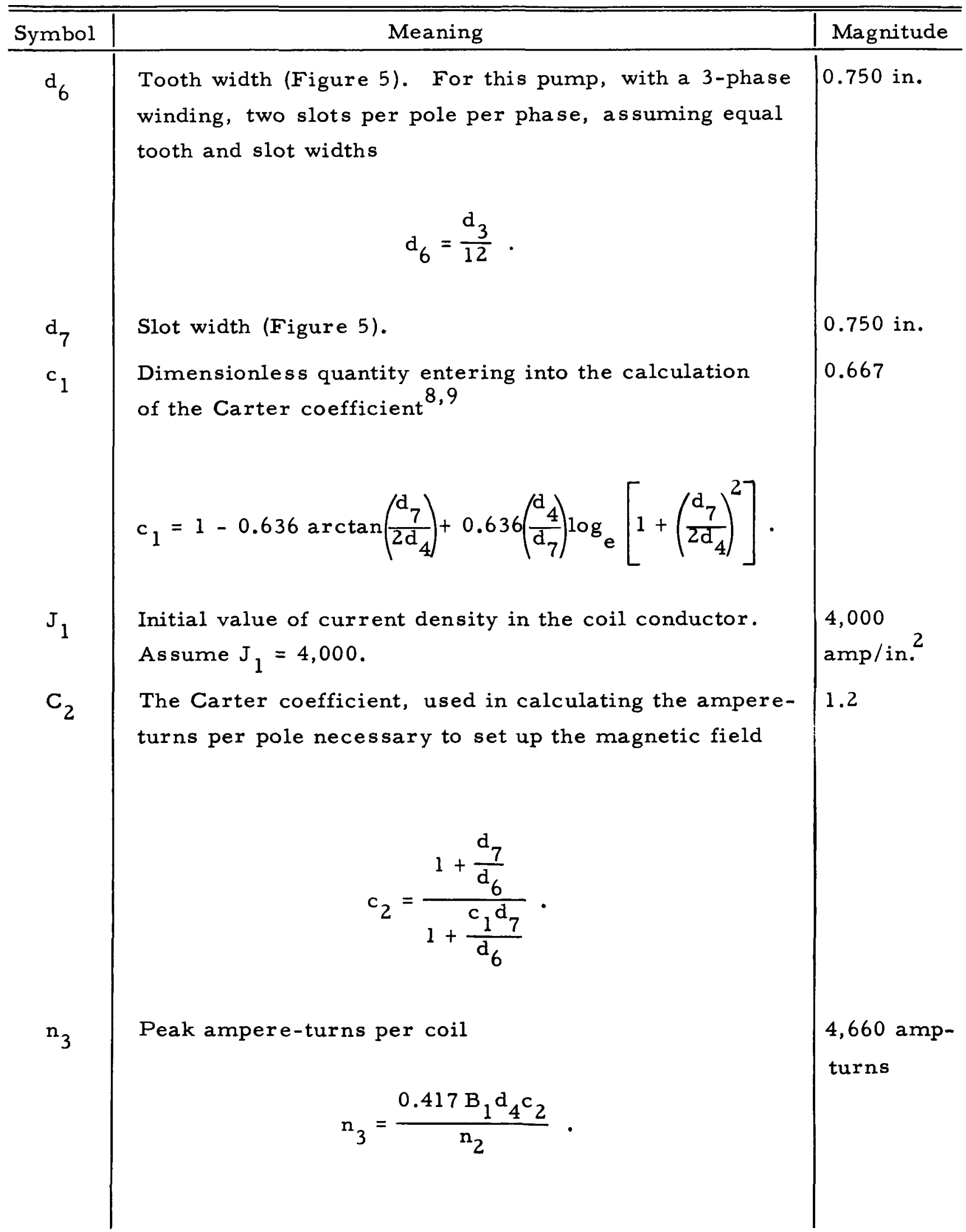




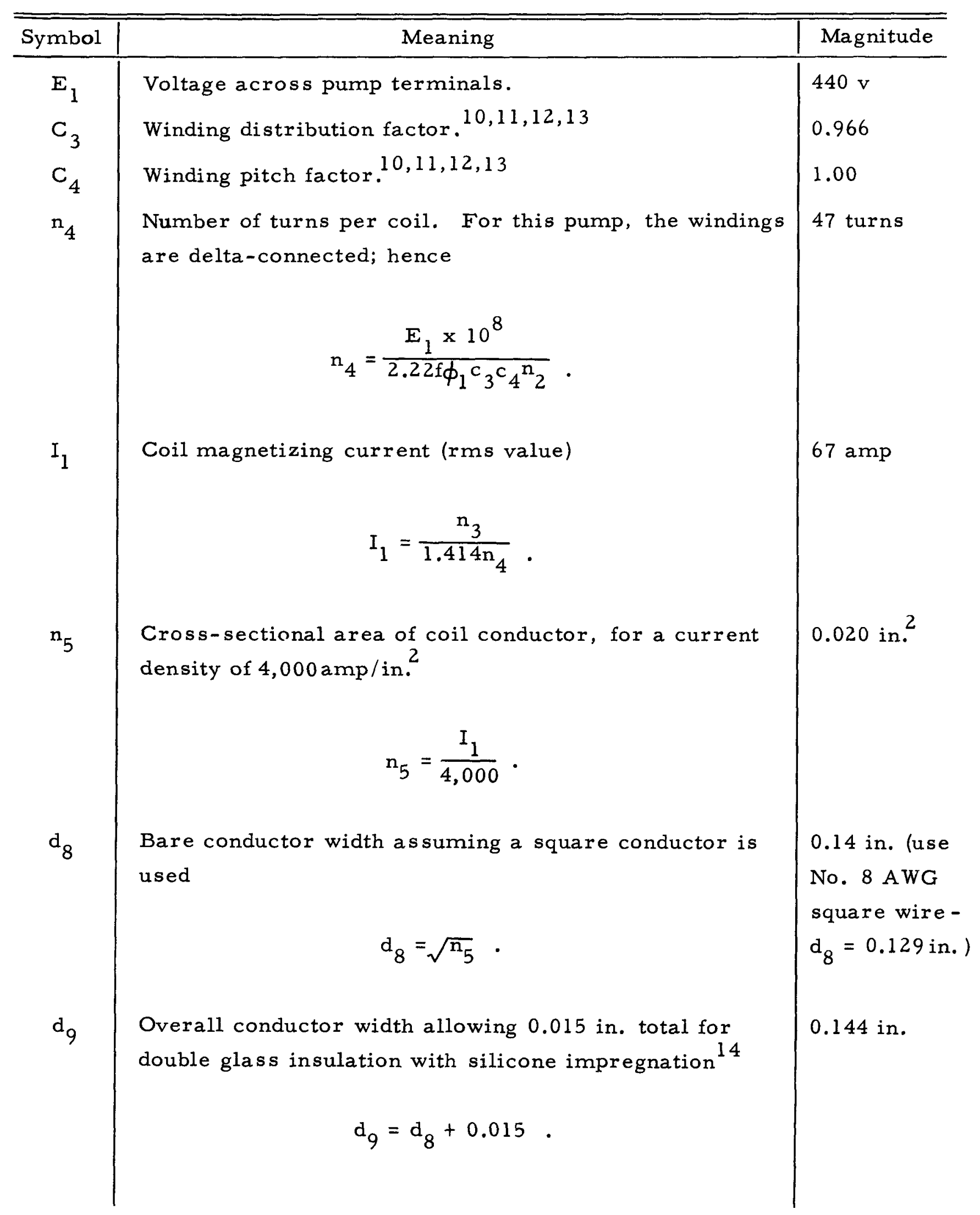




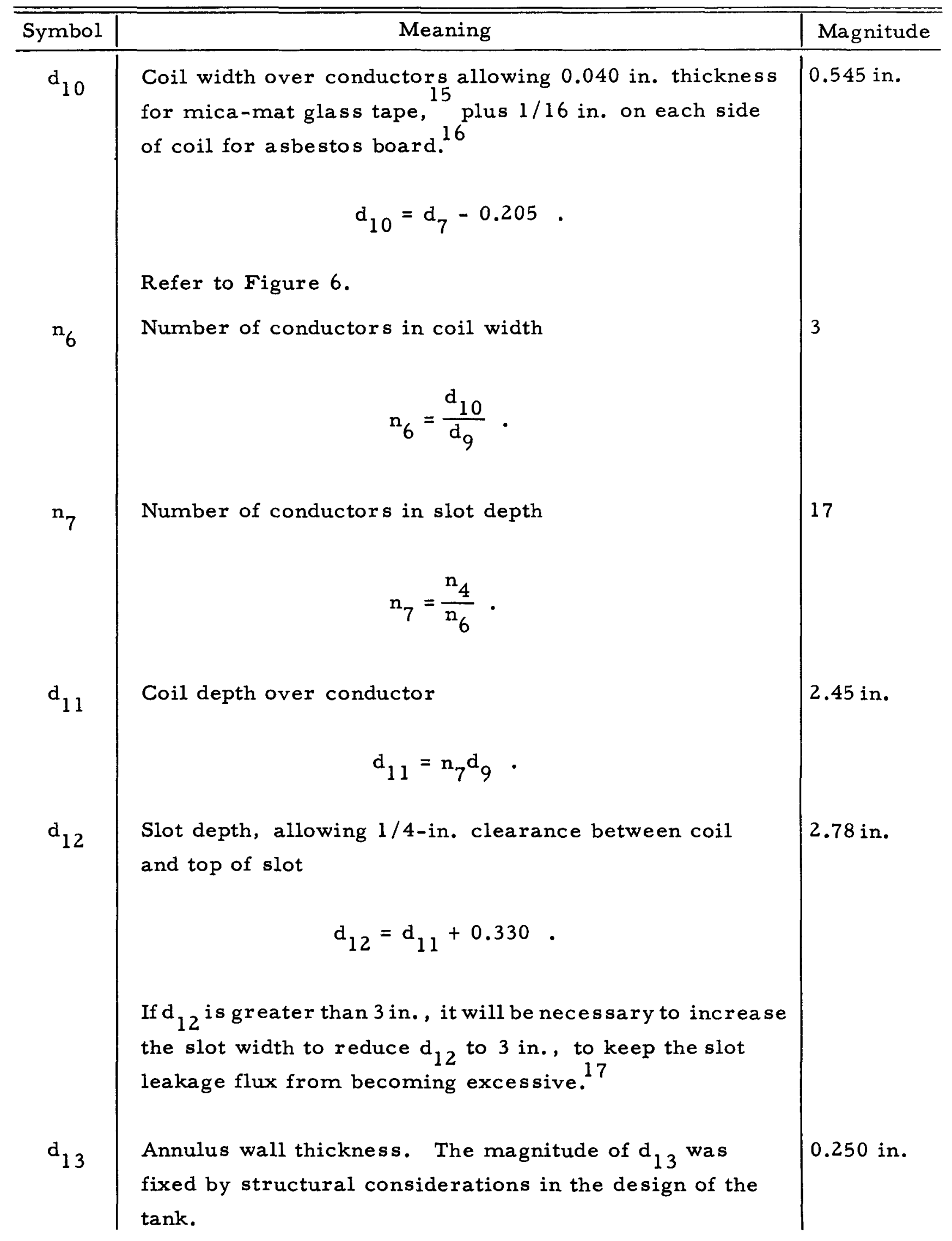




\begin{tabular}{|c|c|c|}
\hline Symbol & Meaning & Magnitude \\
\hline $\mathrm{w}_{1}$ & Power input to sodium & $9,600 \mathrm{w}$ \\
\hline $\mathrm{w}_{2}$ & Power loss in annulus wall & $31,400 \mathrm{w}$ \\
\hline $\mathrm{w}_{3}$ & $\begin{array}{l}\text { Stator and flux return path iron loss. This item is } \\
\text { calculated by determining total weight of silicon steel } \\
\text { laminations and multiplying by } 3 \mathrm{w} / 1 \mathrm{~b} .\end{array}$ & $2,000 \mathrm{w}$ \\
\hline $\mathrm{w}_{4}$ & $\begin{array}{l}\text { Copper loss in stator winding. Since this item can- } \\
\text { not be accurately determined without knowing the value } \\
\text { of total coil current, and since total coil current can- } \\
\text { not be determined until all losses are known, assume } \\
\mathrm{W}_{4}=\mathrm{W}_{3} \text {. }\end{array}$ & $4,000 w$ \\
\hline $\mathrm{w}_{5}$ & $\begin{array}{l}\text { Total power input } \\
\qquad \mathrm{w}_{5}=\mathrm{w}_{1}+\mathrm{w}_{2}+\mathrm{w}_{3}\end{array}$ & $45,000 \mathrm{w}$ \\
\hline $\mathrm{I}_{2}$ & $\begin{array}{l}\text { Energy component of coil current (rms value) } \\
\qquad I_{2}=\frac{W_{5}}{3 n_{1} E_{1}}\end{array}$ & $17.1 \mathrm{amp}$ \\
\hline
\end{tabular}




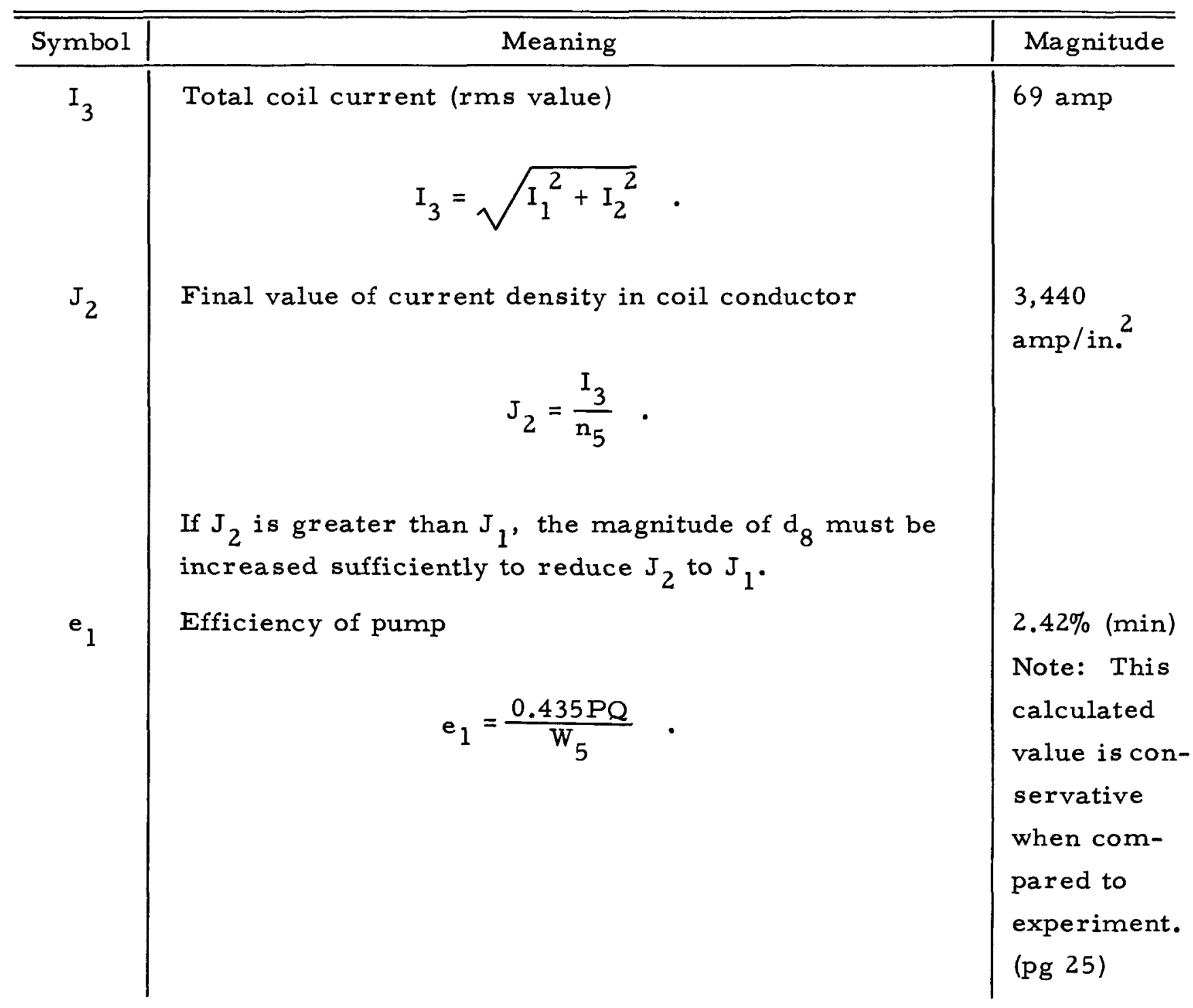




\section{(4)}

B. DERIVATION OF EXPRESSION FOR $n_{3}$, THE PEAK AMPERE-TURNS PER COIL

$$
\mathrm{ATP}=\text { ampere-turns per pole }
$$

$0.313 \mathrm{~B}_{1} \mathrm{~d}_{4} \mathrm{c}_{2}=\mathrm{ATP}$ for one crossing of the gap whose length is $\mathrm{d}_{4}$

$$
\begin{aligned}
& 0.626 \mathrm{~B}_{1} \mathrm{~d}_{4} \mathrm{c}_{2}=\mathrm{ATP} \text { total } \\
& 0.626 \mathrm{~B}_{1} \mathrm{~d}_{4} \mathrm{c}_{2}=1.5 \mathrm{ATP} / \text { phase }^{17}
\end{aligned}
$$$$
\text { ATP/phase }=n_{3} n_{2}
$$

$$
\mathrm{n}_{3}=\frac{0.417 \mathrm{~B}_{1} \mathrm{~d}_{4} \mathrm{c}_{2}}{\mathrm{n}_{2}}
$$

C. DERIVATION OF THE FACTOR 0.435 IN THE EQUATION FOR EFFICIENCY (IV B)

When the pump is operating at a constant flow of $Q$ and a constant differential pressure across the pump of $P$, the pump is working at a rate of $W_{0}$ watts, given by the equation

$$
\begin{aligned}
\mathrm{W}_{0}= & \text { (Net force in pounds due to differential pressure) times } \\
& \text { (velocity of sodium flow in feet per minute) times } \\
& \left(2.26 \times 10^{-2}\right. \text { watts per foot pound per minute). }
\end{aligned}
$$

Now the net force (lb) is equal to the differential pressure (psi) times the internal cross-section area(in. ${ }^{2}$ ) of the sodium flow passage.

The velocity of sodium flow ( $\mathrm{ft} / \mathrm{min}$ ) is equal to the flow ( $\mathrm{gal} / \mathrm{min}$ ) times $0.134\left(\mathrm{ft}^{3} / \mathrm{gal}\right)$ divided by the quantity (internal cross-section area in square in. divided by 144 in. ${ }^{2} / \mathrm{ft}^{2}$.

Denote the internal cross-section area (in. ${ }^{2}$ ) by $\mathrm{A}$; the velocity of the sodium flow (ft/min) by v; and the net force (lb) by $F$.

Then

$$
\begin{aligned}
& P=P \cdot A \\
& v=\frac{Q \times 0.134}{\frac{A}{144}}=\frac{Q}{A} \times 19.3
\end{aligned}
$$




$$
\begin{aligned}
& \mathrm{W}_{0}=\mathrm{F} \times \mathrm{v} \times 2.26 \times 10^{-2}=\mathrm{P} \cdot \mathrm{A} \cdot \frac{\mathrm{Q}}{\mathrm{A}} \cdot 19.3 \times 2.26 \times 10^{-2} \\
& \mathrm{~W}_{0}=0.435 \mathrm{PQ} \text { watts. }
\end{aligned}
$$




\section{(AI)}

\section{REFERENCES}

1. J. R. Churchill, "A $250 \mathrm{Mw}-$ Electrical Advanced Sodium Graphite Reactor," NAA-SR-3829 (to be published), p 9

2. J. F. Asti, "Final Report-Development of Electromagnetic Pumps for Liquid Metals, "Report Number 43-109 (Allis-Chalmers Mfg. Co., June 30, 1952)

3. D. A. Watt, "Electromagnetic Pumping of Liquid Metals, "Atomic Energy Research Establishment Report, ED/R 1824

4. R. S. Baker, "Calculation of Developed Pressure and Fluid Power in Linear Polyphase Induction Pumps," Mine Safety Appliances Company Technical Report 48, (March 24, 1956)

5. Liquid Metals Handbook, (Washington D.C., Government Printing Office, 1952 and 1955)

6. "Stainless Steel Handbook," Allegheny-Ludlum Steel Co., 1956 ed., Pittsburgh, Pa.

7. R. S. Baker, op. cit., Equation 97, p 39

8. J. F. Asti, op. cit., Appendix F, p 40

9. Magnetic Circuits and Transformers, by MIT Electrical Engineering Staff (John Wiley and Sons, Inc, 1943) Equation 39, p 90

10. J. F. Asti, op. cit., Appendix 2, p 66

11. J. H. Kuhlmann, Design of Electric Apparatus, (3rd ed, John Wiley and Sons, Inc, 1950) pp 174, 193, 296

12. A. Still and C. S. Siskind, Elements of Electrical Machine Design (3rd ed, McGraw-Hill Book Co., Inc, 1954) p 172

13. P. L. Alger, The Nature of Polyphase Induction Machines, (John Wiley and Sons, Inc, 1951) Equation 3.17, p 68

14. Magnet Wire, Publication Number C-79-12A (Anaconda Wire and Cable Co, 25 Broadway, New York 4, N. Y.)

15. Product of The National Electric Coil Company, Columbus, Ohio

16. Product of Johns-Manville Corporation, 22 East 40th St., N. Y. 16, N. Y.

17. R. M. Baker, "Transverse Flux Induction Heating, " AIEE Transactions, 1950, Vol 69, part 2, Equation 37, p 716

18. J. H. Kuhlmann, op. cit., p 432, also Appendix 6, p 488 